\title{
Antioxidant activities of Lampaya medicinalis extracts and their main chemical constituents
}

\author{
Glauco Morales ${ }^{1,2^{*}}$ and Adrián Paredes ${ }^{1}$
}

\begin{abstract}
Background: Lampaya medicinalis Phil. (Verbenaceae) is a plant used by Aymara and Quechua ethnic groups from Northern Chile as folk medicine in the treatment and cure of various diseases. The aim of this study was to investigate the in vitro antioxidant activity, total phenols content, total flavonoids content, total antioxidant activity, reducing power, brine shrimp cytotoxicity and identify the principal chemical constituents.

Methods: The crude hydroethanolic extract (HEE) and its partitioned fraction: hexane (HF), dichloromethane (DF), ethyl acetate (EAF), n-butanol (BF) and soluble residual aqueous fraction (RWF) were evaluated for their antioxidant activity using different assays namely, DPPH, ABTS, FRAP, $\beta$-carotene bleaching assay. The content of total phenolics and total flavonoids were measured by Folin-Ciocalteau and by the $\mathrm{AlCl}_{3}$ colorimetric method, respectively. Reducing power was determined by phosphomolybdate and hexacyanoferrate (III) methods. Biotoxicity assays were performed on shrimps of Artemia salina. The EAF was fractionated using chromatographic methods.
\end{abstract}

Results: Considerable amount of phenolic and flavonoid contents were recorded in the hydroethanolic extract (HEE) and its derived fractions. Although HEE and all its derived fractions exhibited good antioxidant activities, the most distinguished radical scavenging potential was observed for ethyl acetate fraction (EAF). EAF showed the higher radical scavenging activity by DPPH (95\%) and by ABTS (98\%), antioxidant activity by FRAP (158.18 $\pm 5.79 \mathrm{mg}$ equivalent Trolox/g fraction), $\beta$-carotene bleaching assay (86.8\%), the highest total phenols content (101.26 $\pm 1.07 \mathrm{mg} \mathrm{GAE} / \mathrm{g}$ fraction), the highest total flavonoids content $(66.26 \pm 3.31 \mu \mathrm{g}$ quercetin $/ \mathrm{g}$ fraction). The EAF extract showed an reducing power of $78 \%$ and $65 \%$ using the phosphomolybdate and hexacyanoferrate (III) assays, respectively. Four flavonoids, two p-hydroxyacetophenone derivatives and one iridoid were isolated from Lampaya medicinalis for the first time.

Conclusion: EtOAc soluble fraction (EAF) shows the strongest antioxidant activity, and it can be attributed to its high content in phenolic and flavonoid compounds. It can be concluded that L.medicinalis can be used as an effective natural source of antioxidant, as ethnomedicine and as a commercial basis for the development of nutraceuticals.

Keywords: Lampaya medicinalis, Hydroethanolic extract, Antioxidant activity, Flavonoids

\section{Background}

Free radicals are chemical species which contain one or more unpaired electrons in their outer shell. They are highly unstable and cause damage to other molecules by extracting electrons from them in order to attain stability. Free radicals result from an imbalance between the generation of Reactive Oxygen Species (ROS) and the antioxidant protection conferred by enzymatic systems.

\footnotetext{
* Correspondence: glauco.morales@uantof.cl

'Laboratorio de Química Biológica, Instituto Antofagasta (IA), Universidad de Antofagasta, Antofagasta, Chile

2Departamento de Química, Facultad de Ciencias Básicas, Universidad de Antofagasta, Antofagasta, Chile
}

Since 1950s, free radical reactions are directly involved in aging and progression of several diseases $[1,2]$. In the past few years, there has been growing interest in the involvement of ROS in several pathological situations. The oxidation induced by ROS can result in cell membrane disintegration, membrane protein damage and DNA mutation, which can further initiate or propagate the development of many diseases, such as cancer, diabetes, liver injury, arteriosclerosis and cardiovascular disease [3]. Although the human body possesses physiological defense mechanisms that reduce the damaging properties of ROS, continuous exposure to various factors and pathological 
conditions can lead to an increase in the amount of free radicals and cause irreversible oxidative damage. In humans the over-production of ROS can result in tissue injury and has been implicated in disease progression. Free radicals have been associated with several diseases such as inflammation, cardiovascular accidents, cancer, agingrelated disorders and atherosclerosis [4].

When there is a lack of materials to quench the excess of reactive free radicals, oxidative stress occurs which can lead to serious diseases. Free radicals then react with various cellular components causing serious damage. So there is a great need for antioxidant supplements to avoid conflict oxidative damage. In the food industry, an antioxidant is defined as a substance that, in low concentrations, is capable of preventing or delaying oxidation of easily oxidizable biomolecules. In mechanistic terms, an antioxidant can be defined as a hydrogen donor or an electron donor. The use of plants as food and medicinal remedies from ancient times is partially attributed to biological efficacy of secondary metabolites that possess antioxidant activities such as phenolic compounds [5]. Medicinal plants are popular remedies used by a majority of the world's population. The efficacy of medicinal plant in the management of diseases is indubitable. The World Health Organization estimated that $80 \%$ of the population of developing countries continues to use traditional medicine in primary medical problems. Over the last few years, investigation of medicinal properties of various plants attracted an increasing interest due their pharmacological activities [6].

Medicinal plants comprise a source of biologically active compounds, which possess different chemical structures and diverse biological activities, and they may, due to the synergistic actions act as powerful antioxidants. Among these compounds, flavonoids and phenolic compounds, phytochemicals with a wide distribution in nature, have been the subject of several studies on their antioxidant activity, which is mainly due to their ability to act as free radical scavengers and/or a metal chelator. There is an increasing interest in the natural antioxidant contained in medicinal plants, which are candidates for the prevention of oxidative damage [7].

Andean High Plateau in Northern Chile, known as "Puna atacameña", is a particular biotope characterized by varying altitudes of between 3000-4200 meters above sea level, a very low relative humidity, no rains, and cloudless skies during most of the year. Around 5000 people live in this peculiar ecological system and they use medicinal plants as curatives or palliatives of health problems because the plants are recognized as a traditional way to treat ailments and diseases [8].

Lampaya medicinalis Phil (Verbenaceae) commonly known, as "lampaya" is a small bush, with a height of $80-100 \mathrm{~cm}$ that grows in the "Puna atacameña" in
Northern Chile. There is little or no information about the chemical composition or medicinal properties of this plant in the scientific literature [9]; however, oral reports from herbal medical practitioners indicate that the infusion of the plant is usually prepared and given for treatment of colds, stomach pain, urinary bladder discomforts, as antitussive, and against rheumatism, arthritis and body joints pain [10-13].

The antioxidant activity of hydroethanolic extract and its partitioned fraction was investigated against several in vitro models. Since free radicals are different chemicals entities, it is essential to test the material against many free radicals to prove its antioxidant activity. This paper reports the evaluation of the antioxidant activities of hydroethanolic extract (HEE) and its partitioned fraction of Lampaya medicinalis, using different assays namely, 2,2-diphenyl-1-picrylhydrazyl (DPPH) and 2,2'-Azino bis(3-ethylbenzothiazoline-6-sulfonic acid (ABTS), $\beta$-carotene bleaching assay, Ferric reducing/Antioxidant Power assays (FRAP). The content of total phenolics and total flavonoids were measured by Folin-Ciocalteau and by the $\mathrm{AlCl}_{3}$ colorimetric method, respectively.

Reducing power was determined by phosphomolybdate and hexacyanoferrate (III) methods. Biotoxicity assay was performed on shrimps of Artemia salina. $\mathrm{IC}_{50}$ values obtained were compared with the standards used. In addition, this paper describes chromatographic separation of the EAF fraction from HAE of this plant and the isolation of two p-hydroxyacetophenones, one iridoid and four flavones.

\section{Methods}

\section{General}

Melting point was determined in a Electrothermal 9100 (ThermoFisher Scientific) and no correction were made. The absorption spectra in the infrared were obtained using a FT-IR Nicolet Avatar 330 using $\mathrm{KBr}$ pellets. The nuclear magnetic resonance spectra of ${ }^{1} \mathrm{H}$ and ${ }^{13} \mathrm{C}, 1 \mathrm{D}$ NMR and 2D NMR were recorded on a Bruker Avance $400 \mathrm{Mhz}$, spectrometer with TMS as internal standard, using $\mathrm{CDCl}_{3}$ and DMSO as solvent. The ultraviolet spectra were recorded on Varian spectrophotometer Model Cary 50. A Thermo Spectronic Genesys20 UV-VIS Spectrometer was used for colorimetric measurement. The Mass Spectra were recorded on Micromass AutoSpec - Ultima NT, spectrometer. Silica gel (200-300 mesh) and silica gel $\mathrm{GF}_{254}$ plates were purchased from Merck (Chile). 2,2-diphenyl-1-picrylhydrazyl (DPPH), 2,2'-azino-bis(3ethylbenzothiozoline-6-sulphonic acid) diammonium salt (ABTS), Folin-Ciocalteu reagent, 6-hydroxy-2,5,7,8-tetramethylchroman-2-carboxylic acid (Trolox), 2,4.6-tri-(2pyridyl)-s-triazine (TPTZ), $\beta$-carotene, trichlroacetic acid, linoleic acid, gallic acid, ascorbic acid, rutin and quercetin 
were purchased from Sigma-Aldrich (Chile). All other reagents and solvents from local sources were of analytical grade.

\section{Plant material}

Leaves and aerial parts of Lampaya medicinalis Phil. were collected at Socaire in Northern Chile $\left(23^{\circ} 36^{\prime} 40\right.$ s S; $67^{\circ} 50^{\prime} 33 \mathrm{~s} \mathrm{~W}, 3230 \mathrm{~m}$ above sea level). The material was identified by Professor Dr. Roberto Rodríguez, Facultad de Ciencias Naturales y Oceanográficas de la Universidad de Concepción, and voucher specimens are kept at the Herbarium (CONC) of Departamento de Botánica de la Universidad de Concepción, Chile.

\section{Extraction and fractionation procedure}

The air-dried leaves of Lampaya medicinalis Phil. $(4.2 \mathrm{Kg})$ were chopped and exhaustively extracted with EtOH: $\mathrm{H}_{2} \mathrm{O}$ $(1: 1,10 \mathrm{~L})$ during one week at room temperature. The solution was filtered, evaporated in vacuo, and lyophilized to give a dried powder extract $(1020 \mathrm{~g})$. This powder (930 g) suspended in 51 methanol:water (1:9) and partitioned in succession with $5 \mathrm{~L}$ of $\mathrm{n}$-hexane, $5 \mathrm{~L}$ of dichloromethane, $5 \mathrm{~L}$ of ethyl acetate and $5 \mathrm{~L}$ of n-butanol. After removal of the solvent in vacuo, the following residues were sequentially obtained: $n$-hexane-soluble (HF, $20 \mathrm{~g})$, dichloromethane-soluble (DF, $150 \mathrm{~g}$ ), ethyl-acetate-soluble (EAF, $300 \mathrm{~g}$ ), butanol-soluble (BF, $250 \mathrm{~g}$ ), and finally residual water-soluble fraction (RWF, $170 \mathrm{~g})$. A sample (15 g) was scooped out from each fraction, freeze-dried and stored in a refrigerator at $4^{\circ} \mathrm{C}$ until further use.

\section{Determination of total antioxidant content Total phenols content}

$1 \mathrm{~mL}$ of the HEE and its derived fractions (HF, DF, EF, BF and RWF) $(10 \mathrm{mg} / \mathrm{mL})$ were mixed with $1 \mathrm{~mL}$ of Folin-Ciocalteu's reagent, previously diluted with water 1:10 v/v. After $5 \mathrm{~min}, 10 \mathrm{~mL} \mathrm{Na}_{2} \mathrm{CO}_{3}$ (7\%) was added. Mixture was thoroughly mixed with $13 \mathrm{~mL}$ of distilled water and incubated at $23^{\circ} \mathrm{C}$ in the dark. After $90 \mathrm{~min}$, absorbance was recorded at $750 \mathrm{~nm}$. A standard solution of gallic acid serial dilution $(25-300 \mu \mathrm{g} / \mathrm{mL}$ in $10 \% \mathrm{EtOH})$, was used to prepare a calibration curve. These data allowed to generate the lineal regression; the equation of the direct line was obtained and it was used for the calculation of the experimental concentration of samples. Estimation of phenolic compounds was recorded and expressed as mg of Gallic Acid Equivalents (GAE) per g of dried extract [14]. Data for each extract was recorded in triplicate and expressed as mean value.

\section{Total flavonoids content}

The total flavonoids content was estimated by a colorimetric procedure using $\mathrm{AlCl}_{3}$ and $\mathrm{NaOH}$ [15]. Aliquot parts $250 \mu \mathrm{L}$ of each extract $(10 \mathrm{mg} / \mathrm{mL}$, dissolved in respective solvent) was mixed with $1.25 \mathrm{~mL}$ of distilled water in a test tube, followed by addition of $75 \mu \mathrm{L}$ of a $15 \% \mathrm{w} / \mathrm{v} \mathrm{NaNO}_{2}$ solution. After 6 min, $150 \mu \mathrm{L}$ of $10 \%$ $\mathrm{w} / \mathrm{v} \mathrm{AlCl}_{3}$ solution was added, and the mixture was allowed to stand for a further $5 \mathrm{~min}$ before $0.5 \mathrm{~mL}$ of $1 \mathrm{M} \mathrm{NaOH}$ was added. The mixture was made up to $2.5 \mathrm{~mL}$ with distilled water and mixed well.

The absorbance was measured immediately at $510 \mathrm{~nm}$. A standard solution of quercetin $(2.5-250 \mu \mathrm{g} / \mathrm{mL}$ in EtOH) was used to prepare a calibration curve. These data allowed to generate the lineal regression, the equation of the direct line was obtained and it was used for the calculation of the experimental concentration of samples. The results of the samples were expressed as mg quercetin equivalents per $\mathrm{g}$ the dry extract.

\section{Determination of antioxidant activity ABTS assay}

HEE, HF, DF, EF, BF and RWF were tested by using the ABTS assay. The assay involve the use of a pre-formed ABTS radical cation (2,2'-azinobis (3-ethylbenzothiozoline-6-sulphonic acid diammonium salt, $\mathrm{ABTS}^{+}$) The assay is based on the discoloration of ABTS by antioxidant compounds, thus reflecting the amount of ABTS radical that are scavenged in relation to that of 6-hydroxy-2, 5, 7, 8-tetramethylchroman-2-carboxylic acid (Trolox) with spectrophotometric analysis [16]. The stock solution of $\mathrm{ABTS}^{+}$cation radical was prepared by mixing equal volumes of $7 \mathrm{mM}$ ABTS in $\mathrm{H}_{2} \mathrm{O}$ and $2.45 \mathrm{mM}$ potassium persulfate solution followed by incubation for $12 \mathrm{~h}$ at room temperature in the dark to yield a dark - colored solution. Working solution was prepared freshly before each assay by diluting the stock solution with phosphate buffered saline solution (PBS) ( $\mathrm{pH}$ 7.4) for an absorbance of $0.70 \pm 0.02$ at $734 \mathrm{~nm}$ and equilibrated at $23^{\circ} \mathrm{C}$. Free radical scavenging activity was assessed by mixing 300 $\mu \mathrm{L}$ of different fractions $(25-250 \mu \mathrm{g} / \mathrm{mL}$, in respective solvents) with $3 \mathrm{~mL}$ of ABTS working solution. The decrease in absorbance was measured exactly $1 \mathrm{~min}$ after mixing the solution, the final absorbance was noted up to $6 \mathrm{~min}$. Determinations were repeated three times for each sample solution. The percentage inhibition of absorbance at $734 \mathrm{~nm}$ was calculated for each concentration relative to a blank absorbance (methanol), plotted as a function of concentration compound or standard Trolox. Inhibition of ABTS radical scavenging activity was calculated according to the equation $\mathrm{AA}(\%)=\left[\left(\mathrm{A}_{\text {blank }}-\right.\right.$ $\left.\left.A_{\text {sample }}\right) / A_{\text {blank }}\right] \times 100$, where $A_{\text {sample }}$ is the absorbance of sample or standard, and $A_{\text {blank }}$ is the absorbance of the ABTS solution only. All tests were run in triplicate and averaged. The results reported are expressed as their $\mathrm{IC}_{50}$ through Graph prism pad software. 


\section{DPPH radical scavenging activity}

The free-radical scavenging activity of various fractions, gallic acid and ascorbic acid was measured with the stable radical diphenylpicryhydrazyl (DPPH) in terms of hydrogen donating or radical scavenging activity. DPPH (3.9 $\mathrm{mL}, 0.075 \mathrm{mM}$, in methanol) solution was added to $100 \mu \mathrm{L}$ of different fractions (dissolved in respective solvent), at different concentration $(1-250 \mu \mathrm{g} / \mathrm{mL})$. After storage at room temperature for $30 \mathrm{~min}$, the absorbance was measured at $517 \mathrm{~nm}$ against a blank [17]. Inhibition of DPPH radical scavenging activity was calculated according to the equation $\mathrm{AA}(\%)=\left[\left(\mathrm{A}_{\text {blank }}-\mathrm{A}_{\text {sample }}\right) /\right.$ $\left.A_{\text {blank }}\right] \times 100$, where $A_{\text {sample }}$ is the absorbance of sample or standard, and $A_{\text {blank }}$ is the absorbance of the DPPH solution only and $\mathrm{IC}_{50}$ value was calculated by graph pad prism software. All test were run in triplicate and averaged.

\section{Ferric reducing/antioxidant power FRAP assay}

Ferric reducing/antioxidant power was measured according to the method described by Suarez et al. with some modification [18]. The stocks solutions included $300 \mathrm{mM}$ acetate buffer $\left(3.1 \mathrm{~g} \mathrm{C}_{2} \mathrm{H}_{3} \mathrm{NaO}_{2} \cdot 3 \mathrm{H}_{2} \mathrm{O}\right.$ and $16 \mathrm{~mL}$ acetic acid, pH 3.6), $10 \mathrm{mM}$ TPTZ (2,4.6-tripyridyl-s-triazine) solution in $40 \mathrm{mM} \mathrm{HCl}$, and $20 \mathrm{mM} \mathrm{FeCl} 3 \cdot 6 \mathrm{H}_{2} \mathrm{O}$ solution were prepared. The fresh working solution (FRAP reagent) was prepared by mixing $25 \mathrm{~mL}$ acetate fuffer, $2.5 \mathrm{~mL}$ TPTZ solution, and $2.5 \mathrm{~mL} \mathrm{FeCl} 3.6 \mathrm{H}_{2} \mathrm{O}$ solution. Plant extract samples $(100 \mu \mathrm{L}, 1 \mathrm{mg} / \mathrm{mL})$ and deionized water $(300 \mu \mathrm{L})$ were mixed with $3 \mathrm{~mL}$ of the FRAP reagent and allow to react for $5 \mathrm{~min}$ in the dark. Readings of the colored product [ferrous tripyridyltriazine complex] were then taken at $539 \mathrm{~nm}$. The results were expressed as $\mathrm{mg}$ of Trolox equivalent/g extract [19].

\section{$\beta$-carotene bleaching method}

The inhibition activity of $\beta$-carotene oxidation by peroxide radicals of samples was determined as described by $\mathrm{Wu}$ et al. [20]. $1 \mathrm{~mL}$ of $\beta$-carotene solution $(0.020 \%$ in chloroform) was pipette into a flask containing $20 \mathrm{mg}$ of linoleic acid and $200 \mathrm{mg}$ of Tween 40. After evaporation of chloroform, $100 \mathrm{~mL}$ of distilled water was added with vigorous agitation to form an emulsion. $2 \mathrm{~mL}$ of this emulsion and $100 \mu \mathrm{L}$ of sample $(50-250 \mu \mathrm{g} / \mathrm{mL})$ were transferred into a test tube. The mixture was then gently mixed and placed in a water bath at $50^{\circ} \mathrm{C}$ for $2 \mathrm{~h}$. Absorbance of solution was recorded at $470 \mathrm{~nm}$ every $20 \mathrm{~min}$ up to $120 \mathrm{~min}$. Quercetin or ascorbic acid can be used as standard antioxidant, positive control. As a negative control was used $50 \%$ aqueous methanol in place of the sample. A Tween 20 solution is used as a blank. The results were based upon two different parameters of the antioxidant activity (AA\%) and oxidant rate ratio $\left(\mathrm{R}_{\mathrm{OR}}\right)$. The rate of $\beta$-carotene bleaching ( $R$ ) was calculated according to equation $\mathrm{R}=\left[\ln \left(\mathrm{A}_{\mathrm{o}} / \mathrm{A}_{\mathrm{t}}\right)\right] / \mathrm{t}$, where $\ln$ is natural logarithm, $A_{o}$ is Absorbance of the emulsion at time $0, A_{t}$ is Absorbance at time $t$, and $t$ is $20,40,60$, 80,100 or $120 \mathrm{~min}$. The AA\% was calculated according to the following equation: $A A \%=\left[R_{\text {blank }}-R_{\text {sample }} / R_{\text {blank }}\right] \times$ 100 , where $R_{\text {sample }}$ and $R_{\text {blank }}$ represent the bleaching rates of $\beta$-carotene with or without the addition of sample, respectively. The $R_{O R}$ was calculated according to equation $\mathrm{R}_{\mathrm{OR}}=\left(\mathrm{R}_{\text {sample }} / \mathrm{R}_{\text {blank }}\right)$.

\section{Determination of reducing power \\ Phosphomolybdate method}

Reducing power was determined by phosphomolybdate method, using ascorbic acid as standard [21]. Reagent solution included $0.6 \mathrm{M}$ sulfuric acid, $28 \mathrm{mM}$ sodium phosphate and $4 \mathrm{mM}$ ammonium molybdate. Different concentrations $(10-200 \mu \mathrm{g} / \mathrm{mL})$ of sample solutions were prepared from the stock solution. An aliquot of $100 \mu \mathrm{L}$ of sample solution was mixed with $1 \mathrm{~mL}$ of reagent solution. The tubes were capped and incubated in a water bath at $95^{\circ} \mathrm{C}$ for $90 \mathrm{~min}$. Samples had cooled to room temperature, the absorbance of mixture was measured at $765 \mathrm{~nm}$ against the blank. A typical blank contained $1 \mathrm{~mL}$ of the reagent solution and the appropriate volume of solvent and incubated under the same conditions. Ascorbic acid was used as standard. Increased Absorbance of the reaction mixture indicated higher total antioxidant capacity. Reducing power was estimated using following formula: Reducing power $(\%)=\left[\left(\mathrm{A}_{\text {blank }}-\mathrm{A}_{\text {sample }}\right) / \mathrm{A}_{\text {blank }}\right] \times$ 100 where $A_{\text {sample }}$ is the absorbance of sample, and $A_{\text {blank }}$ is the absorbance of blank solution, containing all reagents except the test sample.

\section{Hexacyanoferrate (III) assay}

The reducing power of all fractions and ascorbic acid were determined based on the method described by Rahman et al. [22]. Different concentrations $(10-200 \mu \mathrm{g} / \mathrm{mL})$ of sample solutions were prepared from the stock solution. $100 \mu \mathrm{L}$ of sample solution was combined with $2.5 \mathrm{~mL}$ of $1 \%$ potassium hexacyanoferrate (III). After the mixture was incubated at $50^{\circ} \mathrm{C}$ for $20 \mathrm{~min}, 2.5 \mathrm{~mL}$ of $10 \%$ trichloroacetic acid was added to mixture, which was centrifuged at $3000 \mathrm{rpm}$ for $10 \mathrm{~min}$. Finally, $2.5 \mathrm{~mL}$ of the supernatant was mixed with $2.5 \mathrm{~mL}$ of distilled water and $0.5 \mathrm{~mL}$ of $0.1 \% \mathrm{FeCl}_{3}$ solution. The absorbance was measured at $700 \mathrm{~nm}$ against a blank. The control contained all reagents except the extract fraction while water was used as blank. Ascorbic acid was used as a standard. Higher absorbance indicates higher reducing power. The increase of reducing power by the extract and standard was calculated as follows: Percentage of increase reducing power $=\left[\left(\mathrm{A}_{\text {test }}-\mathrm{A}_{\text {control }}\right) / \mathrm{A}_{\text {test }}\right] \times 100$, where $A_{\text {test }}$ is absorbance of test solution and $\mathrm{A}_{\text {control }}$ is absorbance of control [23]. 


\section{Biotoxicity assays against Artemia salina}

The bioactivity of each extract was monitored by the brine shrimp lethality test against Artemia salina Leach naupliis according to previously described methods, in three independent 36 -h exposure experiments at $22-25^{\circ} \mathrm{C}$. Artemia salina eggs were incubated at room temperature for $48 \mathrm{~h}$ with the help of a light source, in seawater boiled and filtered [24,25]. Ten nauplii were used to test each dose of extract HEE, HF, DF, EAF, BF and RWF (1000, 100 and $10 \mu \mathrm{g} / \mathrm{mL}$, in triplicates). Survivors were counted with the aid of a magnifying glass. After $36 \mathrm{~h}$ of incubation and maintaining the vials under illumination, the deaths at each dose level and controls were determined. The number of dead nauplii were used for calculating the $\mathrm{LC}_{50}$ at $95 \%$ confidence limit by the Finney Probit analysis program. $\mathrm{HgCl}_{2}$ was used as a positive control, methanol was used as solvent, brine shrimp larvae in only sea water were taken as a negative control.

\section{Statistical analysis}

All data were expressed as means \pm SD. Analysis of variance was performed by ANOVA procedure. Duncan's new multiple-range test was used to determine the differences of means, and $p<0.05$ was considered to be statistically significant.

\section{Isolation and identification of compounds (1-7)}

A sample of EAF was separated by successive column chromatography over silica gel using n-hexane and EtOAc gradient with increasing amounts of EtOAc to obtain three crystalline colourless and four crystalline yellow products.

Structure assignments of natural products were done based on their physical and spectroscopic properties: UV, IR, NMR and MS analysis and comparison with data reported in the literature.

\section{5-hydroxy -7,4'-dimethoxyflavone}

1. Yellow crystal, mp $173-174^{\circ} \mathrm{C}$ (EtOAc - n-hexane). ${ }^{1} \mathrm{H}$ NMR (300 Mz, $\left.\mathrm{CDCl}_{3}\right) \delta 3.88$ (3H, s, OMe), $3.90(3 \mathrm{H}, \mathrm{s}$, OMe), $6.58(1 \mathrm{H}, \mathrm{s}, \mathrm{H}-3), 6.37(1 \mathrm{H}, \mathrm{d}, \mathrm{J}=2.2 \mathrm{~Hz}, \mathrm{H}-6)$, $6.48(1 \mathrm{H}, \mathrm{d}, \mathrm{J}=2.2 \mathrm{~Hz}, \mathrm{H}-8), 7.84(2 \mathrm{H}, \mathrm{d}, \mathrm{J}=9.1 \mathrm{~Hz} \mathrm{H}-2$ ' and $\left.\mathrm{H}-6^{\prime}\right), 7.02\left(2 \mathrm{H}, \mathrm{d}, \mathrm{J}=9.1 \mathrm{~Hz} \mathrm{H}-3^{\prime}\right.$ and $\left.\mathrm{H}-5^{\prime}\right), 7.98$ $(1 \mathrm{H}, \mathrm{s}, \mathrm{OH}), 12.10$ (H, s, OH-5). ${ }^{13} \mathrm{C} \mathrm{NMR}\left(75 \mathrm{Mz}, \mathrm{CDCl}_{3}\right.$, DMSO) $\delta 163.35$ (C-2), 104.27 (C-3), 182.30 (C-4), 157.60 (C-5), 98.20 (C-6), 165.60 (C-7), 92.90 (C-8) 152.60 (C-9), 105.00 (C-10), 122.59 (C-1'), 126.36 (C-2'), 114.48 (C-3'), 161.63 (C-4'), 114.48 (C-5'), 126.36 (C-6'), 56.10 (OMe, C-4'), 55.00 (OMe, C-7).

\section{5-hydroxy-7,3',4'-trimethoxyflavone}

2. Yellow needles, $\mathrm{mp} 163-165^{\circ} \mathrm{C}$ (EtOAc-n-hexane). ${ }^{1} \mathrm{H}$ NMR $\left(300 \mathrm{Mz}, \mathrm{CDCl}_{3}\right) \delta 3.82(3 \mathrm{H}, \mathrm{s}, \mathrm{OMe}), 3.85$ (3H, s, OMe), 3.89 (3H, s, OMe), 6.50 (1H, s, H-3), 6.29 $(1 \mathrm{H}, \mathrm{d}, \mathrm{J}=2.3 \mathrm{~Hz}, \mathrm{H}-6), 6.41(1 \mathrm{H}, \mathrm{d}, \mathrm{J}=2.3 \mathrm{~Hz}, \mathrm{H}-8), 7.25$ $\left(1 \mathrm{H}, \mathrm{d}, \mathrm{J}=2.2 \mathrm{~Hz} \mathrm{H}-2^{\prime}\right), 6.91$ (2H, d, J=8.6 Hz H-5'), 7.45 $\left(1 \mathrm{H}, \mathrm{dd}, \mathrm{J}=8.6,2.2 \mathrm{~Hz} \mathrm{H}-6\right.$ '), 12.10 (H, s, OH-5). ${ }^{13} \mathrm{C}$ NMR $\left(75 \mathrm{Mz}, \mathrm{CDCl}_{3}\right) \delta 163.80$ (C-2), 103.07 (C-3), $179.14(\mathrm{C}-4)$, 163.30 (C-5), 98.20 (C-6), 167.60 (C-7), 92.90 (C-8), 156.60 (C-9), 106.00 (C-10), 122.99 (C-1'), 114.90 (C-2'), 147.48 (C-3'), 149.00 (C-4'), 114.90 (C-5'), 121.00 (C-6'), 56.50 (OMe, C-4'), 56.20 (OMe, C-3'), 55.90 (OMe, C-7).

\section{5,4'-dihydroxy-7,3'-dimethoxyflavone}

3. Yellow needles, velutin, $\mathrm{mp} 216-218^{\circ} \mathrm{C}$ (EtOAc - nhexane). ${ }^{1} \mathrm{H}$ NMR (300 Mz, $\left.\mathrm{CDCl}_{3}\right) \delta 3.81$ (3H, s, OMe), $3.93(3 \mathrm{H}, \mathrm{s}, \mathrm{OMe}), 6.42(1 \mathrm{H}, \mathrm{s}, \mathrm{H}-3), 6.30(1 \mathrm{H}, \mathrm{d}, \mathrm{J}=2.3$ $\mathrm{Hz}, \mathrm{H}-6), 6.51(1 \mathrm{H}, \mathrm{d}, \mathrm{J}=2.3 \mathrm{~Hz}, \mathrm{H}-8), 7.25(1 \mathrm{H}, \mathrm{d}, \mathrm{J}=2.2$ $\left.\mathrm{Hz} \mathrm{H}-2^{\prime}\right), 6.97$ ( $\left.2 \mathrm{H}, \mathrm{d}, \mathrm{J}=8.6 \mathrm{~Hz} \mathrm{H}-5^{\prime}\right), 7.43$ (1H, dd, $\left.\mathrm{J}=8.6,2.2 \mathrm{~Hz} \mathrm{H}-6{ }^{\prime}\right), 12.72(\mathrm{H}, \mathrm{s}, \mathrm{OH}-5) .{ }^{13} \mathrm{C} \mathrm{NMR}$ $\left(75 \mathrm{Mz}, \mathrm{CDCl}_{3}\right) \delta 163.92$ (C-2), 103.23 (C-3), 180.62 (C-4), 161.05 (C-5), 96.30(C-6), 165.15 (C-7), 92.70 (C-8) 155.90 (C-9), 106.50 (C-10), 123.59 (C-1'), 114.90 (C-2'), 147.48 (C-3'), 145.10 (C-4'), 119.00 (C-5'), 121.60 (C-6'), 55.75 (OMe, C-4'), 55.90 (OMe, C-7),

\section{5,4'-dihydroxy-6,7,3'-trimethoxyflavone}

4. Yellow needles, cirsilineol, mp 204-206 ${ }^{\circ} \mathrm{C}$ (EtOAc-nhexane). ${ }^{1} \mathrm{H}$ NMR (300 Mz, DMSO) $\delta 3.75$ (3H, s, OMe), 3.91 (3H, s, OMe), 3.93 (3H, s, OMe), $6.86(1 \mathrm{H}$, s, H-3), $6.94(1 \mathrm{H}, \mathrm{s}, \mathrm{H}-8), 7.59\left(1 \mathrm{H}, \mathrm{d}, \mathrm{J}=2.2 \mathrm{~Hz} \mathrm{H}-2^{\prime}\right)$, $6.95\left(2 \mathrm{H}, \mathrm{d}, \mathrm{J}=8.6 \mathrm{~Hz} \mathrm{H}-5^{\prime}\right), 7.58(1 \mathrm{H}, \mathrm{dd}, \mathrm{J}=8.6,2.2 \mathrm{~Hz}$ $\left.\mathrm{H}-6{ }^{\prime}\right), 12.95$ ( $\left.\mathrm{H}, \mathrm{s}, \mathrm{OH}-5\right) .{ }^{13} \mathrm{C}$ NMR $\left(75 \mathrm{Mz}, \mathrm{CDCl}_{3}\right) \delta$ 163.98 (C-2), 103.23 (C-3), 182.62 (C-4), 162.65 (C-5), 131.90 (C-6), 158.65 (C-7), 91.68 (C-8), 152.50 (C-9), 106.50 (C-10), 121.39 (C-1'), 103.10 (C-2'), 148.10 (C-3'), 150.78 (C-4'), 120.50 (C-5'), 118.70 (C-6'), 56.40 (OMe, C-4'), 55.99 (OMe, C-7), 60.00 (OMe, C-6).

\section{p-hydroxyacetophenone}

5. Colorless crystal, mp $109-111^{\circ} \mathrm{C} .{ }^{1} \mathrm{H}$ NMR $(300 \mathrm{Mz}$, $\left.\mathrm{CDCl}_{3}\right) \delta 2.57(3 \mathrm{H}, \mathrm{s}, \mathrm{COMe}), 6.54(1 \mathrm{H}, \mathrm{s}, \mathrm{OH}), 6.92$ $(2 \mathrm{H}, \mathrm{d}, \mathrm{J}=8.8 \mathrm{~Hz} \mathrm{H}-3$ and H-5), $7.91(2 \mathrm{H}, \mathrm{d}, \mathrm{J}=8.8 \mathrm{~Hz} \mathrm{H}-2$ and $\mathrm{H}-6) .{ }^{13} \mathrm{C}$ NMR $\left(75 \mathrm{Mz}, \mathrm{CDCl}_{3}\right) \delta 26.25(\mathrm{Me}), 115.53$ (C-3 and C-5), 129.66 (C-1), 131.19 (C-2 and C-6), 161.27 (C-4), 198.50 (CO).

\section{4-O- $\beta$-D-glucopyranosyl acetophenone}

6. Colorless crystal, picein, mp $195^{\circ} \mathrm{C} .{ }^{1} \mathrm{H}$ NMR $(300 \mathrm{Mz}$, DMSO) $\delta 2.38$ (3H, s, COMe), $3.20\left(1 \mathrm{H}, \mathrm{m}, \mathrm{H}-4^{\prime}\right), 3.30$ (1H, m, H-2'), 3.32 (1H, m, H-3'), 3.70 (1H, m, H-5'), $4.41\left(1 \mathrm{H}, \mathrm{d} J=11.0 \mathrm{~Hz} \mathrm{H}-6^{\prime}\right), 4.17(1 \mathrm{H}$, dd $\mathrm{J}=11.0$ and $\left.7.3 \mathrm{~Hz} \mathrm{H}-6^{\prime}\right), 5.07$ (H, d, J=9.0 Hz H-1'). ${ }^{13} \mathrm{C}$ NMR $\left(75 \mathrm{Mz}, \mathrm{CDCl}_{3}\right) \delta 26.25(\mathrm{Me}), 116.07(\mathrm{C}-3$ and $\mathrm{C}-5)$, 130.98 (C-1), 130.23 (C-2 and C-6), 160.92 C-4), 196.45 (CO), 63.30 (C-6'), 70.15 (C-4'), $73.23\left(\mathrm{C}-2^{\prime}\right), 74.02,\left(\mathrm{C}-5^{\prime}\right)$, 76.43, (C-3'), $99.62\left(\mathrm{C}-1^{\prime}\right)$. 


\section{Genipin}

7. Colorless crystal, mp $120-122^{\circ} \mathrm{C}\left(\mathrm{Et}_{2} \mathrm{O}\right) .{ }^{1} \mathrm{H}$ NMR $\left(300 \mathrm{Mz}, \mathrm{CDCl}_{3}\right) \delta 2.08(1 \mathrm{H}, \mathrm{m}, \mathrm{H}-6), 2.55(1 \mathrm{H}, \mathrm{m}, \mathrm{H}-9)$, $2.90(1 \mathrm{H}, \mathrm{m}, \mathrm{H}-6), 3.22(1 \mathrm{H}, \mathrm{m}, \mathrm{H}-5), 3.74(3 \mathrm{H}, \mathrm{s}$, COOMe), $4.33(2 \mathrm{H}, \mathrm{d}, \mathrm{J}=8.6 \mathrm{~Hz} \mathrm{H}-10), 4.83(1 \mathrm{H}, \mathrm{d}$, $\mathrm{J}=8.6 \mathrm{~Hz} \mathrm{H}-1) 5.88$ (1H, H-7), $7.53(1 \mathrm{H}, \mathrm{H}-3) .{ }^{13} \mathrm{C}$ NMR $\left(75 \mathrm{Mz}, \mathrm{CDCl}_{3}\right) 168.17$ (COOMe), 152.74 (C-3), 142.26 (C-8), 130.13 (C-7), 110.96 (C-4), 95.33 (C-1), 61.53 (C-10), 51.50 (Me), 48.38 (C-9), 39.24 (C-6), 36.22 (C-5).

\section{Results and discussion}

\section{Determination of total antioxidant content} Total phenols assay and total flavonoids assay

Polyphenols are the most abundant antioxidants in the plant kingdom and it is likely that the antioxidant capacity of extract/fraction might be due to these compounds. Table 1 shows the quantity of total phenolics and total flavonoids content. Total phenols content varied from $101.26 \pm 1.07$ to $27.64 \pm 0.39 \mathrm{mg}$ Gallic acid equivalent $/ \mathrm{g}$ extract/fraction. Maximum quantity of total phenol content was observed in EAF, $101.26 \pm 1.07 \mathrm{mg}$ GAE/g fraction, with a significant difference with the rest of the fractions, followed by HEE and RWF with $49.18 \pm 0.86 \mathrm{mg} \mathrm{GAE} / \mathrm{g}$ fraction and $48.41 \pm 0.91 \mathrm{mg} \mathrm{GAE} / \mathrm{g}$ fraction, respectively. $\mathrm{BF}$ and DF showed the lowest content of phenols with $36.10 \pm 0.37 \mathrm{mg} \mathrm{GAE} / \mathrm{g}$ fraction and 27.64 $\pm 0.39 \mathrm{mg}$ GAE /g fraction, respectively.

The total flavonoid content varied from $66.26 \pm 3.31$ to $11.14 \pm 2.24 \mu \mathrm{g}$ quercetin equivalent/g extract/fraction. Maximum quantity of total flavonoid content was observed in EAF $66.26 \pm 3.31 \mu \mathrm{g}$ quercetin/g fraction, followed by HEE with $60.04 \pm 6.13 \mu \mathrm{g}$ quercetin/g fraction. BF, DF and RWF showed total flavonoid content with $31.64 \pm 2.99 \mu \mathrm{g}$ quercetin/g fraction, $29.29 \pm 3.58 \mu \mathrm{g}$ quercetin/g fraction and $23.39 \pm 1.77 \mu \mathrm{g}$ quercetin/g fraction, respectively. The lowest quantity was observed in HF with $11.14 \pm 2.24 \mu \mathrm{g}$ quercetin/g fraction. It was noted that EAF had the highest total phenol and total flavonoid contents among all fractions.

\section{Determination of antioxidant activity}

Antioxidant properties of different plant extracts can be evaluated using various in vitro assays. Antioxidant assays in biological system can assess lipid peroxidation or can measure free radical scavenging ability. For measuring free radical scavenging ability, methods are grouped into two groups, according to the chemical reaction involved: hydrogen radical transfer and single electron transfer. Single electron transfer based-methods detect the ability of an antioxidant to transfer one electron to reduce any compound, including metals and radicals. Methods based on this principle include a substrate oxidant that abstracts an electron from the antioxidant, causing color changes of the substrate. The degree of color change is proportional to the antioxidant concentrations.

\section{ABTS assay}

ABTS radical scavenging activity involves a more drastic radical, chemically produced and is often used for screening complex antioxidant mixtures such as plant extracts, beverages and biological fluids. The actual version of this assay, a stable ABTS radical cation which has a blue-green chromophore absorption, was produced by oxidation of ABTS with potassium persulfate. Antioxidant activity of the natural products is determined by the discoloration of the ABTS, by measuring the reduction of the absorbance at $734 \mathrm{~nm}$. The extension of discoloration, expressed as a percentage inhibition of $\mathrm{ABTS}^{+}$, is determined as a function of the concentration and it is calibrated against Trolox as the reference standard. The results of ABTS scavenging activity of hydroethanolic extract (HEE) and its partitioned fraction of Lampaya medicinalis,

Table 1 Total phenolics, flavonoids contents and antioxidant activities of diferent fractions from HEE of $L$. medicinalis

\begin{tabular}{|c|c|c|c|c|c|c|c|c|}
\hline Extract & $\begin{array}{c}\text { Total } \\
\text { phenolics }^{\mathrm{a}}\end{array}$ & $\begin{array}{c}\text { Total } \\
\text { flavonoids }^{\mathrm{b}}\end{array}$ & $\mathrm{IC}_{50} \mathrm{ABTS}^{\mathrm{C}}$ & $\mathrm{IC}_{50} \mathrm{DPPH}^{\mathrm{c}}$ & FRAP $^{d}$ & $\begin{array}{c}\mathrm{IC}_{50} \\
\beta \text {-carotene } \\
\text { c }^{\mathrm{c}}\end{array}$ & $\begin{array}{c}\mathrm{IC}_{50} \\
\text { molybdate }^{\mathrm{c}}\end{array}$ & $\begin{array}{c}\mathrm{IC}_{50} \\
\text { Hexacyanoferrate (III) }\end{array}$ \\
\hline HEE & $49.18 \pm 0.86^{\mathrm{e}}$ & $60.04 \pm 6.13^{e}$ & $11.59 \pm 1.21^{\mathrm{e}}$ & $13.79 \pm 0.76^{e, f}$ & $38.29 \pm 1.79^{e}$ & $189.07 \pm 3.13$ & $48.31 \pm 3.13$ & $61.56 \pm 5.13$ \\
\hline $\mathrm{HF}$ & - & $11.14 \pm 2.24$ & $56.32 \pm 1.70$ & $27.17 \pm 0.64$ & - - & 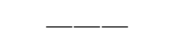 & - - & - - \\
\hline DF & $27.64 \pm 0.39$ & $29.29 \pm 3.58^{f, g}$ & $19.74 \pm 1.17^{f}$ & $20.35 \pm 0.98$ & $56.90 \pm 4.57$ & $252.60 \pm 4.87$ & $26.93 \pm 2.09$ & $110.5 \pm 3.13$ \\
\hline EAF & $101.26 \pm 1.07$ & $66.26 \pm 3.3^{\mathrm{e}}$ & $5.16 \pm 1,09$ & $9.94 \pm 0.18$ & 5.79 & 65.41 & $41.86 \pm 1.56^{\mathrm{e}}$ & $40.23 \pm 3.89$ \\
\hline $\mathrm{BF}$ & $36.10 \pm 0.37$ & $31.64 \pm 2.99^{f}$ & $14.12 \pm 1.45^{\mathrm{e}}$ & $15.09 \pm 1.05^{\mathrm{e}}$ & $109.36 \pm 5.90$ & $117.69 \pm 2.98$ & $37.33 \pm 2.19^{f}$ & $141.62 \pm 4.23$ \\
\hline RWF & $48.41 \pm 0.9^{e}$ & $23.39 \pm 1.77^{9}$ & $22.27 \pm 2.10^{f}$ & $12.49 \pm 0.97^{f}$ & $31.79 \pm 4.56^{e}$ & $370.96 \pm 3.67$ & $40.47 \pm 1.86^{e, f}$ & 162.45 \\
\hline
\end{tabular}

HEE (crude hydroethanolic extract), HF (hexane fraction), DF (dichlorometane fraction), EAF (ethyl acetate fraction), BF (n-butanol fraction), RWF (residual water fraction). All values were expressed as Means $\pm S D(n=3)$.

a expressed in $\mathrm{mg}$ Gallic acid equivalent/g extract.

bexpressed in $\mu \mathrm{g}$ Quercetin/mg extract.

cexpressed in $\mu \mathrm{g} / \mathrm{mL}$ extract.

dexpressed in $\mathrm{mg}$ Trolox equivalent/g.

e, $f, g$ extract in the same column followed by different letter are not significantly different $(p<0.05)$. 
are summarized in Table 1 ( $\mathrm{IC}_{50}$ values). Overall, the $\mathrm{IC}_{50}$ of ABTS free radical scavenging capacity of six extracts was found between $5.16 \pm 1.09$ to $56.32 \pm 1.70 \mu \mathrm{g} / \mathrm{mL}$. EAF, HEE, and BF showed comparatively strong ABTS free radical scavenging capacity. Similarly, DF and RWF showed moderate activity. Figure 1 shows the dose-response curves of ABTS radical activities of extracts from Lampaya medicinalis. It was found that the radicalscavenging activities of all extracts increased with the concentration. All test samples exhibited potent scavenging activities in a concentration dependent manner. At a concentration of $50 \mu \mathrm{g} / \mathrm{mL}$, scavenging activities of EAF reached a plateau of $98 \%$ while, at same concentration, scavenging effects of HEE, DF, BF, RWF and HF were $78 \%, 71 \%, 70 \%, 67 \%$, and $39 \%$, respectively. While at the same concentration the activity of Trolox was $99 \%$. The antioxidant activity of HEE and its fractions and standard Trolox increased in the following order $\mathrm{HF}<\mathrm{RWF}<\mathrm{BF}<$ $\mathrm{DF}<\mathrm{HEE}<\mathrm{EAF} \approx$ Trolox.

\section{DPPH radical scavenging capacity}

2,2-diphenyl-1-picrylhydrazyl (DPPH), in solution, is a stable free radical, which has been widely accepted as a tool for estimating free radical scavenging activities of antioxidants. One of the reasons is that this method is simple and highly sensitive. This assay is based on the theory that a hydrogen donor is an antioxidant. DPPH is one of the few stable and commercially available organic nitrogen radicals. The antioxidant effect is proportional to the disappearance of $\mathrm{DPPH}^{\cdot}$ in test sample. Various methods of monitoring the amount of $\mathrm{DPPH}^{\circ}$ in the antioxidant test system have been reported, however monitoring with UV spectrometer has become the most widely used. $\mathrm{DPPH}^{\circ}$ accepts an electron or hydrogen radical to become a stable diamagnetic molecule. This reaction is stoichiometric with respect to the number of hydrogen atoms absorbed, or to the number of electrons captured. The reduction capability of DPPH radical is determined by the decrease in absorbance at $517 \mathrm{~nm}$ induced by antioxidants. Then, color changing from purple to yellow is the consequence of the reducing ability of antioxidant toward DPPH stable free radical. The higher the discoloration of the DPPH methanol solution, the lower the absorbance of the reaction mixture, indicating thereby significant free radical scavenging capacity. The results have been reported as $\mathrm{IC}_{50}$, which is the amount of antioxidant necessary to decrease the initial $\mathrm{DPPH}^{\circ}$ by $50 \%$ expressed in $\mu \mathrm{g} / \mathrm{mL}$. The results of DPPH scavenging activity of hydroethanolic extract (HEE) and its partitioned fraction of Lampaya medicinalis, are summarized in Table 1 ( $\mathrm{IC}_{50}$ values). Overall, the $\mathrm{IC}_{50}$ of $\mathrm{DPPH}$ free radical scavenging capacity of six samples were found between $9.94 \pm 0.18$ to $27.17 \pm 0.64 \mu \mathrm{g} / \mathrm{mL}$. EAF, RWF, HEE and BF, showed comparatively strong DPPH free radical scavenging capacity. Similarly, DF and HF showed moderate activity. Figure 2 shows the dose-response curves of DPPH radical activities of extracts from Lampaya medicinalis. It was found that all test samples exhibited potent scavenging activities in a concentration dependent manner. At a concentration of $50 \mu \mathrm{g} / \mathrm{mL}$, the scavenging activities of EAF reached a plateau of $95 \%$ while, at same concentration, the scavenging effects of BF, RWF, HEE, DF and HF were $81 \%, 79 \%, 74 \%, 71 \%$ and $60 \%$, respectively.

\section{FRAP assay}

Ferric reducing antioxidant power assay is based on the ability of an antioxidant to reduce $\mathrm{Fe}^{+3}$ to $\mathrm{Fe}^{+2}$ ions in the presence of TPTZ (2,4,6-tris-(2-pyridyl)-s-triazine), forming an intense blue Fe-TPTZ complex with an absorbance maximum at $593 \mathrm{~nm}$. Decreased absorbance is proportional to the antioxidant content. The FRAP assay results of the HEE and its fractions expressed as mg equivalent of Trolox/g fraction are shown in Table 1 . EAF showed the highest reducing power with $158.18 \pm 5.79 \mathrm{mg}$ Trolox

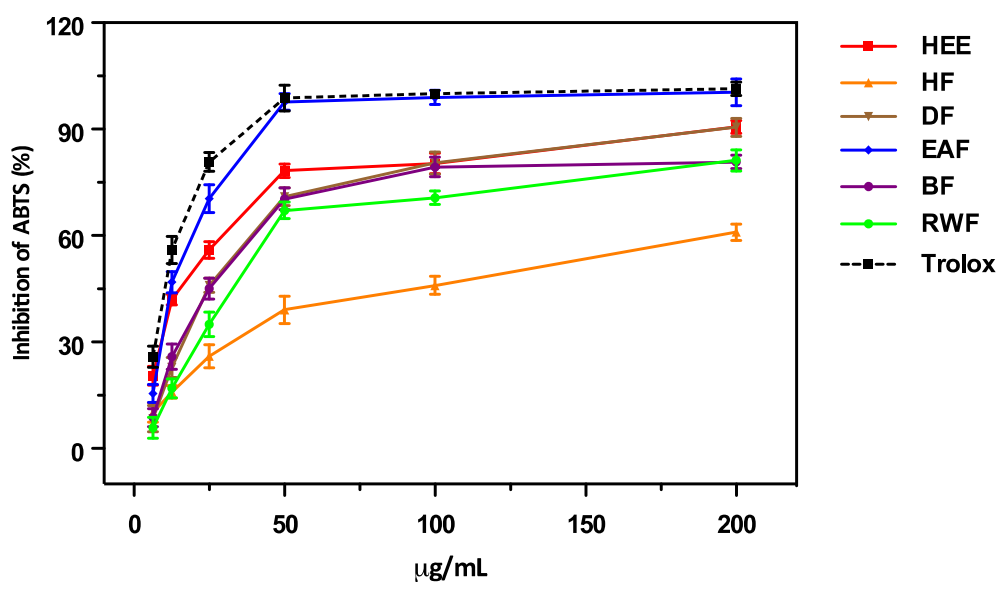

Figure 1 ABTS scavenging activities of crude HEE and its derived fraction of $L$. medicinalis. 


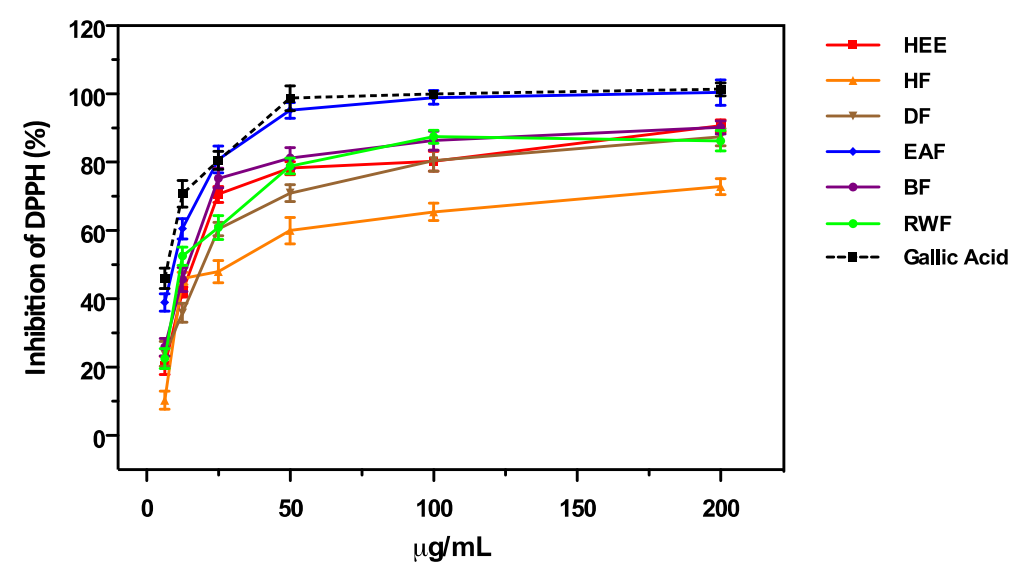

Figure 2 DPPH scavenging activities of crude HEE and its derived fraction of $L$. medicinalis.

equivalent, followed by BF with $109.36 \pm 5.90 \mathrm{mg}$ Trolox equivalent. FRAP values varied from $158.18 \pm 5.79$ to $31.78 \pm 4.56 \mathrm{mg}$ Trolox equivalent. The ferric reducing antioxidant power of HEE and its fractions and Trolox increased in the following order $\mathrm{RWF}<\mathrm{HEE}<\mathrm{DF}<\mathrm{BF}<$ $\mathrm{EAF} \approx$ Trolox.

\section{$\beta$-carotene bleaching method}

It is widely know that $\beta$-carotene reacts with the peroxyl radical to produce $\beta$-carotene epoxides acting as a radical scavenger or antioxidant. The linoleic acid forms a peroxyl radical in the presence of $\mathrm{ROS}$ and $\mathrm{O}_{2}$. In this antioxidant assay a mixture of $\beta$-carotene and linoleic acid is used. The peroxyl radical reacts with $\beta$-carotene, subsequently, the amount of $\beta$-carotene reduces in a testing solution, resulting in the rapid disappearance of color. If an antioxidant is present in a testing solution, it reacts competitively with peroxyl radical and color is maintained for a longer period. Therefore, antioxidant activities are monitored by bleaching the color of a test solution at $470 \mathrm{~nm}$, which is the typical absorbance by $\beta$-carotene. The $\mathrm{IC}_{50}$ values of $\beta$-carotene bleaching assay of Lampaya medicinalis extract and various fractions is summarized in Table 1. Maximum activity was observed by EAF and lowest by RWF with $\mathrm{IC}_{50}$ values of $65.41 \pm 3.56 \mu \mathrm{g} / \mathrm{mL}$ and $370.96 \pm 3.67 \mu \mathrm{g} / \mathrm{mL}$ respectively. The antioxidant activity (\%) of HEE and its fractions and ascorbic acid increased with an increasing concentration of the sample. The antioxidant activity of HEE and its fractions and ascorbic acid increased in the following order $\mathrm{HF}<\mathrm{RWF}<$ $\mathrm{DF}<\mathrm{HEE}<\mathrm{BF}<\mathrm{EAF} \approx$ ascorbic acid. At a concentration of $250 \mu \mathrm{g} / \mathrm{mL}$, EAF and ascorbic acid exhibited $86.78 \pm$ $3.65 \%$ and $86.56 \pm 2.98 \%$ as antioxidant activity, respectively. Figure 3 shows the dose-response curves of $\beta$-carotene bleaching assay of Lampaya medicinalis extract and various fractions.

\section{Reducing power}

\section{Phosphomolybdate assay}

The total antioxidant potential of Lampaya medicinalis extracts and various fractions was estimated from their ability to reduce de Mo (VI) to Mo (V) and resulting in

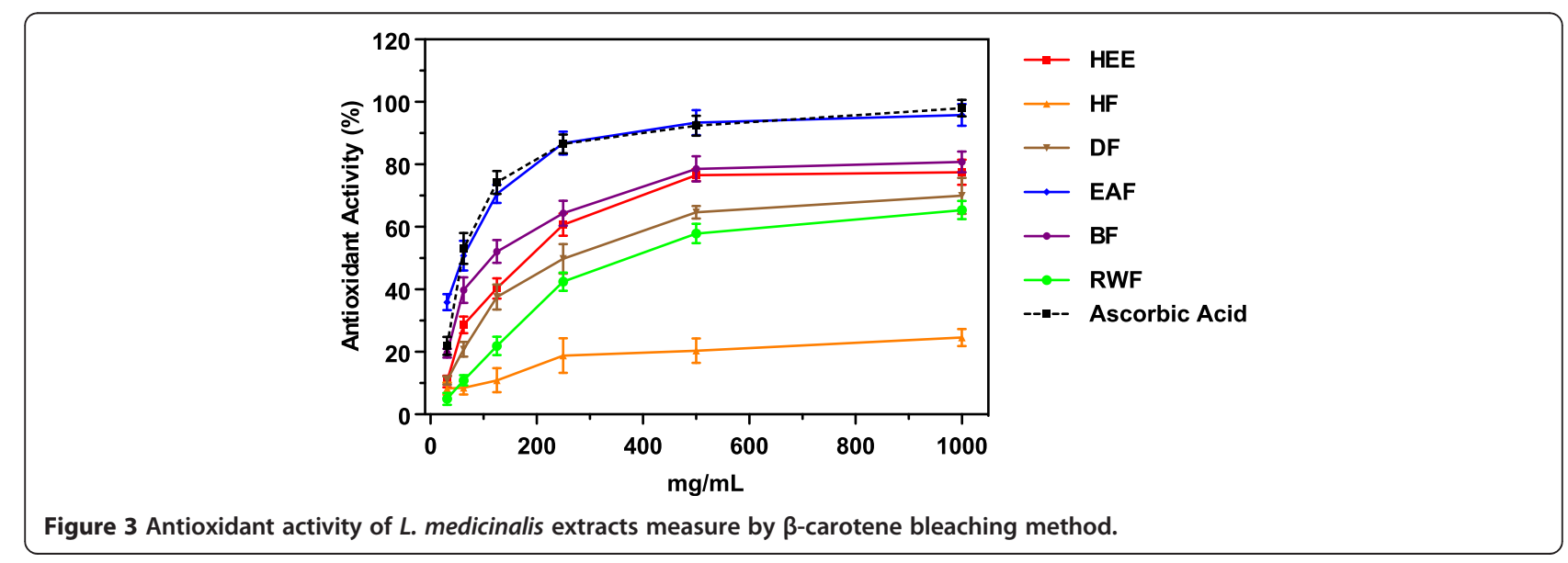




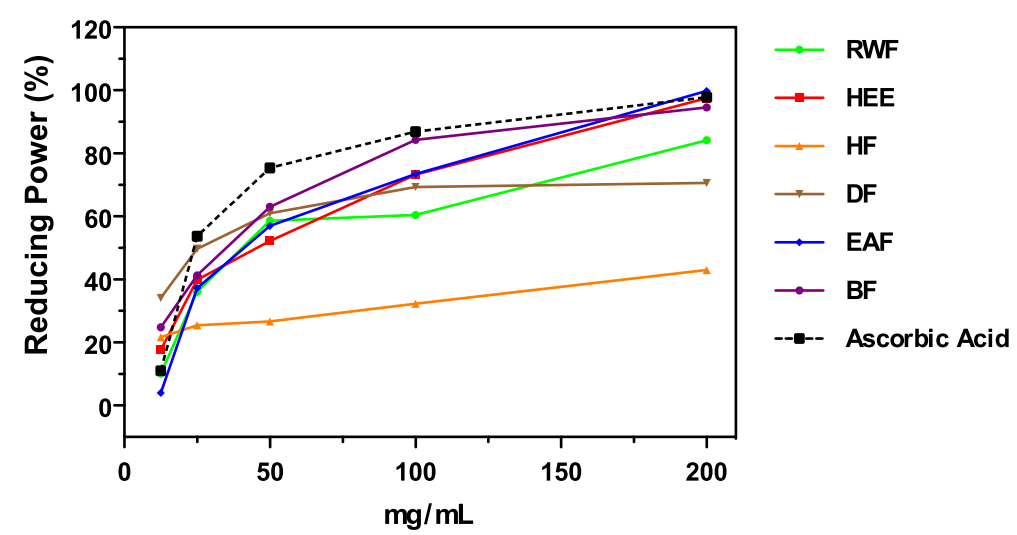

Figure 4 Reducing power of $L$. medicinalis extracts measured by phosphomolybdate method.

formation of green phosphate/Mo (V) complex with maximum absorption at $695 \mathrm{~nm}$. Increased Absorbance of the reaction mixture indicated increased total antioxidant capacity. In the present assay all the different fractions showed good total antioxidant index, which was concentration-dependent. The results of reducing power of hydroethanolic extract (HEE) and its partitioned fraction are summarized in Table 1 ( $\mathrm{IC}_{50}$ values). Overall, the $\mathrm{IC}_{50}$ of five samples were found between $26.93 \pm 2.09$ to $48.31 \pm 3.13 \mu \mathrm{g} / \mathrm{mL}$. Figure 4 shows the dose-response curve of total antioxidant capacity of extracts from Lampaya medicinalis. It was found that all test samples exhibited potent activities in a concentration dependent manner. At a concentration of $100 \mu \mathrm{g} / \mathrm{mL}$, the antioxidant activity of HEE, its fractions and ascorbic acid increased in the following order $\mathrm{HF}<\mathrm{RWF}<\mathrm{DF}<\mathrm{HEE}<\mathrm{EAF}<\mathrm{BF} \approx$ Ascorbic acid.

\section{Hexacyanoferrate (III) assay}

Reduction power, widely used in evaluating antioxidant activity of plants, was determined by the potassium hexacyanoferrate (III) reduction method. In this assay, the presence of reductans in the antioxidant sample causes the reduction of the $\mathrm{Fe}^{+3} /$ Hexacyanoferrate (III) complex to $\mathrm{Fe}^{+2} /$ Hexacyanoferrate (III) complex, so the reducing power of sample can be monitored by measuring the formation Perl's Prussian Blue complex at $700 \mathrm{~nm}$. Increased absorbance indicated increase antioxidant capacity.

The $\mathrm{IC}_{50}$ values of reducing power assay of Lampaya medicinalis extract and various fractions are summarized in Table 1. Maximum activity was observed by EAF and lowest by RWF with $\mathrm{IC}_{50}$ values of $40.23 \pm 3.89 \mu \mathrm{g} / \mathrm{mL}$ and $162.45 \pm 5.11 \mu \mathrm{g} / \mathrm{mL}$ respectively. The reducing activity (\%) of HEE and its fractions and ascorbic acid increased with an increasing concentration of the sample in the following order $\mathrm{HF}<\mathrm{RWF}<\mathrm{DF}<\mathrm{HEE}<\mathrm{BF}<\mathrm{EAF} \approx$ ascorbic acid, as shown in Figure 5. At a concentration of $100 \mu \mathrm{g} / \mathrm{mL}$, the reducing effects of ascorbic acid, EAF, HEE, DF, BF RWF, and HF were $75 \%, 64 \%, 63 \%, 49 \%, 42 \%$ and $32 \%, 27 \%$, respectively.

\section{Biotoxicity assay against Artemia salina}

A general bioassay that seems capable to detecting a wide range of biological properties of crude extracts is

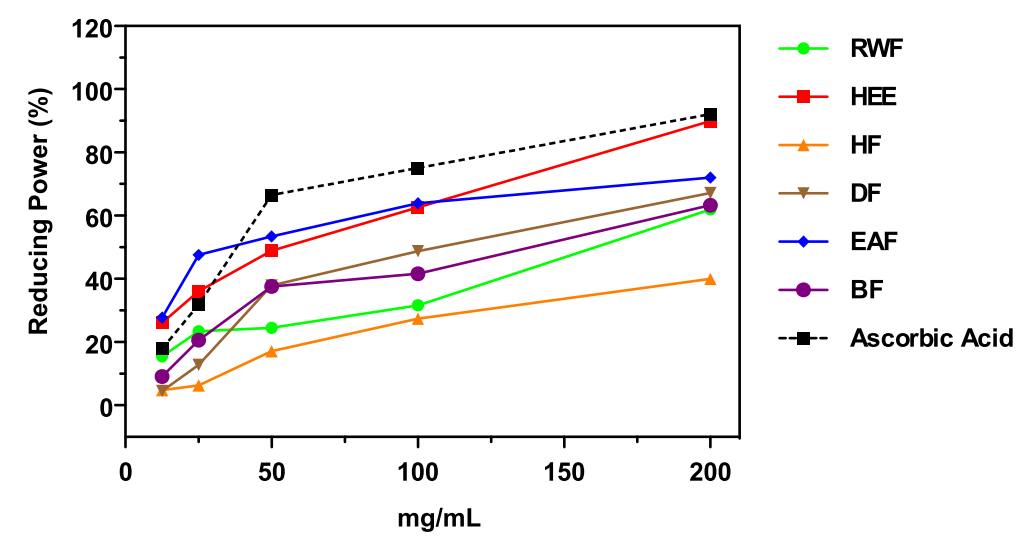

Figure 5 Reducing power of $L$. medicinalis extracts measured by hexacyanoferrate (III) method. 


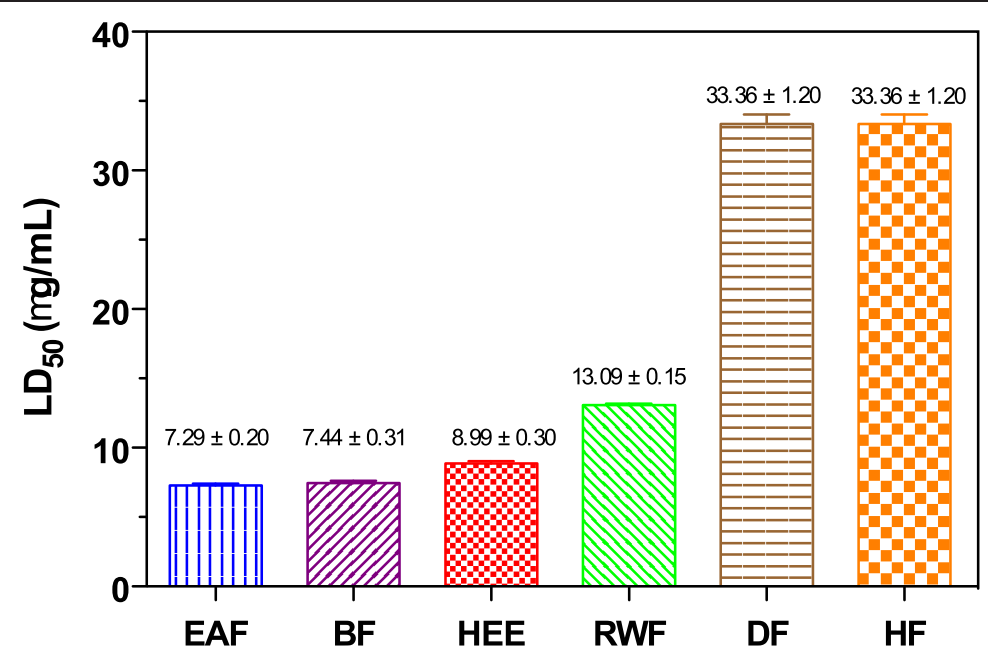

Figure 6 Biotoxicity assays of L. medicinalis extracts against Artemia salina.

the brine shrimp lethality test. The technique is simple, inexpensive and use a small amount of test material, and it has been used to evaluate plants for potential pharmacological activity. In bioactivity evaluation by brine shrimp bioassay, cytotoxic activity is considered weak when the $\mathrm{LC}_{50}$ is between $500-1000 \mu \mathrm{g} / \mathrm{mL}$, moderate the $\mathrm{LC}_{50}$ is between $100-500 \mu \mathrm{g} / \mathrm{mL}$, and strong when the $\mathrm{LC}_{50}$ is between $0-100 \mu \mathrm{g} / \mathrm{mL}$ [26]. The degree of lethality was found to be directly proportional to the concentration of samples. The results of brine shrimp cytotoxicity studies are expressed in Figure 6. 100\% of the larvae of Artemia were alive after $36 \mathrm{~h}$ of experiment in the negative control. All larvae in $\mathrm{HgCl}_{2}$ control died at dose $3 \mu \mathrm{g} / \mathrm{mL}$. Test samples showed $\mathrm{LC}_{50}$ in the range of $33.36 \pm 1.20-7.29 \pm 0.20 \mu \mathrm{g} / \mathrm{mL}$, indicating a strong cytotoxicity activity. Among all tested fractions, EAF $(7.29 \pm 0.20 \mu \mathrm{g} / \mathrm{mL}), \mathrm{BF}(7.44 \pm 0.31 \mu \mathrm{g} / \mathrm{mL})$ and HEE $(8.99 \pm 0.30 \mu \mathrm{g} / \mathrm{mL})$ showed comparatively higher cytotoxic activity. While less bioactive fractions were HF and $\mathrm{DF}$, with $\mathrm{LC}_{50} 33.36 \pm 1.20 \mu \mathrm{g} / \mathrm{mL}$. This result indicates that all fractions of Lampaya medicinalis may contain chemical compounds with pharmacological properties.

\section{Isolation and characterization of compounds 1-7}

This is the first report of the presence of seven compounds in Lampaya medicinalis. The structures of the compounds were based on detailed analysis of UV, IR, 1DNMR, 2DNMR, EM spectral evidence and by comparing data with the literature values. Chromatographic fractionation of EAF led to identification of four compounds belonging<smiles></smiles>

(5)<smiles>CC(=O)c1ccc(OC2OC(CO)[C@@H](O)[C@H](O)[C@H]2O)cc1</smiles><smiles>COC(=O)C1=COC(O)C2C(CO)=CCC12</smiles>

Figure 7 Structures of compounds 1-7 isolated from L. medicinalis. 
to the flavonoid class (1-4), two p-hydroxyacetophenone derivatives (5-6) and one iridoid (7) (Figure 7). The chemical shifts of the signals assignable to the $\mathrm{C}-2, \mathrm{C}-3$ and $\mathrm{C}-4$ of the ring $\mathrm{C}$ in the ${ }^{13} \mathrm{C}$ NMR spectra of compounds 1-4 strongly indicates that these flavonoids belong to the class of flavones. Indeed, these signals are characteristic values and within known ranges for $\mathrm{C}-2 \sim \delta 164, \mathrm{C}-3 \sim \delta$ 103 and $\mathrm{C}-4 \sim \delta 180$, values according to the system double bond conjugated with the carbonyl in $\mathrm{C}-4$ in the ring $\mathrm{C}$ [27]. In the ${ }^{1} \mathrm{H}$ NMR spectra of compounds 1-4 the signal at $\delta \sim 12.3$ is assignable to $\mathrm{OH}$ group attached at $\mathrm{C}-5$ strongly chelated to $\mathrm{CO}$ at $\mathrm{C}-4$. On the basis of physicochemical properties, spectral data (UV, IR, 1D NMR, 2D NMR, EI-MS). Compound 1 have oxygenation patterns as apigenin $5,7,4^{\prime}$, Compounds 2 and 3 have oxygenation patterns as luteolin $5,7,3^{\prime}, 4^{\prime}$ and compound 4 is a 6 luteolin substituted and by comparing the data with the literature values the structures were identified to be 5-hydroxy-7,4'-dimethoxyflavone 1 [28], 5-hydroxy$7,3^{\prime}, 4^{\prime}$-trimethoxyflavone 2 [29,30], 5,4'-dihydroxy-7, 3 '-dimethoxyflavone, velutin 3 [30-32], 5,4'-dihydroxy6,7,3'-trimethoxyflavone, cirsilineol 4 [33,34]. 5,4'-dihy droxy-7,3'-dimethoxyflavone, velutin 3 was isolated earlier from several plants $[32,35,36]$.

This compound possesses a strong anti-inflammatory effect inhibiting the expression of proinflammatory cytokines tumor necrosis factor TNF- $\alpha$ and interleukin IL- 6 in very low micromole levels by inhibiting nuclear factor NF- $\mathrm{KB}$ activation and p38 and JNK phosphorylation in macrophages [37]. 5,4' -dihydroxy-6,7,3'-trimethoxyflavone, cirsilineol 4 was isolated and identified earlier from several plants [38-40]. This compound is interesting for its pronounced antibacterial and antitumor activity [41,42].

Compounds 5 and 6 are p-hydroxyacetophenone and its glucoside 4-O- $\beta$-D-glucopyranosylacetophenone, picein, respectively [43-47]. Compound 7 Genipin, $\mathrm{C}_{11} \mathrm{H}_{14} \mathrm{O}_{5}$, is an aglycone derived from the iridoid glycoside geniposide, which is found in the fruit of Gardenia jasminoides $[48,49]$. Genipin is a hydrolytic product of geniposide. The structure of genipin was discovered in the 1960's. Because it is a naturally occurring biodegradable molecule with low cytotoxicity, genipin has recently been investigated as a crosslinking material in many biological applications. Recent explorations into the use of genipin crosslinking gelatin for use as a bioadhesive, wound dressing, and as bone substitute, have shown it to have potential as a new and safe crosslinking agent. In the area forensic science, genipin is being examined as a new way of developing latent fingerpring on paper products. Because it is an environmentally friendly natural product it shows great potential over the current reagent being used, ninhydrin. It is reported that genipin has many medicinal effects, such as anti-inflammatory [50], anticancer, anthitrombotic, antibacterial, gastritis curative diabetes curative [51].

\section{Conclusions}

The results obtained in this study demonstrate that the hydroethanolic extract of Lampaya medicinalis has strong antioxidant activity in the all methods tested. Its EtOAc soluble fraction (EAF) shows the strongest antioxidants activity and it can be attributed to its high content in phenolic and flavonoid compounds. It can be concluded that L.medicinalis can be used as an effective natural source of antioxidant, as ethnomedicine and as a commercial basis for the development of nutraceuticals.

\section{Competing interests}

The authors declare that they have no competing interests.

\section{Authors' contributions}

GM and AP performed all experiments and read and approved the final manuscript.

\section{Acknowledgement}

This work was funded by the "Fondo de Innovación para la Competitividad Regional", FIC-R, Antofagasta and "Fundación para la Innovación Agraria" FIA grant $N^{\circ}$ EST 2010-0157.

Received: 24 April 2014 Accepted: 16 July 2014

Published: 21 July 2014

\section{References}

1. Gutteridge JMC, Halliwell B: Antioxidants: molecules, medicines and myths. Biochem Biophys Res Commun 2010, 393:561-564.

2. Halliwell B, Gutteridge JMC, Cross CE: Free radicals, antioxidants and human disease: where are we now? J Lab Clin Med Biochem 1992, 119:598-620.

3. Sati SC, Sati N, Rawat U, Sati OP: Medicinal plants as a source of antioxidants. Res J Phytochemistry 2010, 4:213-224.

4. Ganga RB, Madhu KP, Vijaya RAD: Investigation of antioxidant and antiinflammatory activity of leaves of Dalbergia paniculata (Roxb). Asian Pac $J$ Trop Biomed 2012, 5:455-458.

5. Kratchanova M, Denev P, Lojek A, Mihailov A: Evaluation of antioxidant activity of medicinal plants containing polyphenol compounds. Comparison of two extraction systems. Acta Biochim Pol 2010, 57:229-234.

6. Céspedes CL, El-Hafidi M, Pavon N, Alarcón J: Antioxidant and cardioprotective activities of phenolics extracts from fruits of Chilean blackberry Aristotelia chilensis (Elaeocarpaceae), Maqui. Food Chem 2008, 107:820-829.

7. Gülçin I, Alici HA, Cesur M: Determination of in Vitro antioxidant and radical scavenging activities of propofol. Chem Pharm Bul 2005 , 53:281-285.

8. Morales G, Paredes A, Sierra P, Loyola LA: Antioxidant activity of $50 \%$ aqueous-ethanol extract from Acantholippia deserticola. Biol Res 2008, 41:151-155

9. Morales G, Paredes A, Olivares A, Bravo J: Acute oral toxicity and antiinflammatory activity of hydroalcoholic extract from Lampaya medicinalis in rats. Biol Res 2014, 47:6. 1-7.

10. Mellado V, Medina E, San Martin C: Herbolaria Medica de Chile. Santiago de Chile: Ministerio de Salud; 1997:168-169.

11. Castro V: Botánica y pueblos andinos. Centro El Canelo de Nos. San Bernardo. Chile: 2 Congreso de Plantas Medicinales; 1995:49.

12. Monterrey N: Hierbas Medicinales Andinas de la $2^{a}$ Región. Santiago de Chile: Ministerio de Educación; 1994:33-35.

13. Gomez D, Ahumada J, Necul E: Medicina Tradicional Atacameña. Chile: Ministerio de Educación; 1997:61-74.

14. Shah NA, Khan MR, Ahmad B, Noureen F, Rashid U, Khan RA: Investigation on flavonoid composition and anti free radical potential of Sida cordata. BMC Complement Altern Med 2013, 13:276-287.

15. Tai Z, Cai L, Dai L, Sun W, Zhe W, Yang Y, Cao Q, Ding Z: Antioxidant activities of Caragana sinica flower extracts and their main chemical constituents. Molecules 2010, 15:6722-6732. 
16. Khan RA, Khan MR, Sahreen S, Ahmed M: Evaluation of phenolic content and antioxidant activity of various solvent extracts of Sonchus asper (L.) Hill. Chem Central J 2012, 6:12-18

17. Hung P, Maeda T, Miyatake K, Morita N: Total phenolic compounds and antioxidant capacity of wheat graded flours by polishing method. Food Res Inter 2010, 42:185-190.

18. Suarez B, Alvarez AL, García YD, Barrio GD, Lobo AP, Parra F: Phenolic profiles, antioxidant activity and in vitro antiviral properties of apple pomace. Food Chem 2010, 120:339-342.

19. Jimenez-Estrada M, Velázquez-Contreras C, Garibay-Escobar A, SierraCancholas D, Lapizco-Vázquez R, Ortiz-Sandoval C, Burgos-Hernández A, Robles-Zepeda RE: In vitro antioxidant and proliferative activities of plants of the ethnopharmacopeia from northwest of Mexico. BMC Complement Altern Med 2013, 13:12-19.

20. Wu N, Fu K, Fu YJ, Zu YG, Chang FR, Chen YH, Liu XL, Kong Y, Liu W, Gu CB: Antioxidant activities of extracts and main components of pigeonpea [Cajanus cajan (L.) Millsp.] leaves. Molecules 2009, 14:1032-1043.

21. Saeed N, Khan MR, Shabbir M: Antioxidant activity, total phenolic and total flavonoid contents of whole plant extracts Torilis leptophyllaL. BMC Complement Altern Med 2012, 12:221-232.

22. Rahman MA, Imran TB, Islam S: Antioxidative, antimicrobial and cytotoxic effects of the phenolics of Leea indica leaf extract. Saudi J Biol Sci 2013, 20:213-225.

23. Gulcin I, Topal F, Cakmakc R, Bisel M, Goren AC, Erdogan U: Pomological features, nutritional quality, poliphenol content analysis and antioxidant properties of domesticated and three wild ecotype forms of raspberries (Rubus idaeus L.). J Food Sci 2011, 76:585-593.

24. Morales G, Sierra P, Paredes A, Loyola LA, Bórquez J: Constituents of Helenium atacamense. Cabr. J Chil Quim Soc 2006, 51:769-772.

25. Nguta JM, Mbaria JM, Gakuya DW, Gathumbi PK, Kabasa JD, Kiama SG: Evaluation of acute toxicity of crude plant extracts from Kenyan biodiversity using brine shrimp, Artemia salina L. (Artemiidae). Open Conf Proc J 2012, 3:30-34

26. Oketch-rabah HA, Dossaji JF, Mberu EK: Antimalarial activity of some Kenyan medicinal plants. Pharm Biol 1999, 37:329-334.

27. Markham KR, Chari VM: Carbon-13 NMR Spectroscopy of Flavonoids. In The Flavonoids: Advances in Research. Edited by Harborne JB, Mabry T. London: Chapman and Hall Ltd; 1982:19-134.

28. Kolak U, Hacibekiroğlu I, Özturk M, Özgokce F, Tocpu G, Ulubelen A: Antioxidant and anticholinesterase constituents of Salvia poculata. Turk J Chem 2009, 33:813-823.

29. Yang GE, Bao L, Zhang XA, Wang Y, Li Q, Zhang WK, Ye WC: Studies on flavonoids and their antioxidant activities of Artemisia annua. J Chin Med Mat 2009, 32:1683-1688.

30. Çitoğlu GS, Server B, Antus S, Baitz-Gács E, Altanlar N: Antifungal Flavonoids from Ballota glandulosissima. Pharm Biol 2003, 41:483-486

31. Kang J, Xie C, Li Z, Nagarajan S, Schauss AG, Wu T, Wu X: Flavonoid from acai (Euterpe oleracea Mart.) pulp and their antioxidant and antiinflammatory activities. Food Chem 2011, 128:152-157.

32. Suleimenov EM, Jose RA, Rakhmadieva SB, De Borggraeve W, Dehaen W: Flavonoids from Senecio viscosus. Chem Nat Comp 2009, 45:731-732.

33. Tashenov EO, Dzhalmakhanbetova RI, Smagulova FM, Dudkin RV, Gorovi PG, Suleiman EM, Ross SA: Cirsilineol and cubreuva lactone from Artemisia umbrosa and their biological activity. Chem Nat Comp 2013, 49:97-98.

34. Nagao $T$, Abe F, Kinjo J, Okabe H: Antiproliferative constituents in plants 10. Flavones from the leaves of Lantana montevidensis Briq. And consideration of structure-activity relationship. Biol Pharm Bull 2002, 25:875-879.

35. Ribeiro EP, Conserva LM, Guilhon GMSP: Flavonoids and triterpenes from the leaves of Lindackeria paraensis. Biochem Syst Ecol 2010, 38:447-449.

36. Cao S, Clare Guza R, Miller JS, Andriantsiferana R, Rasamison VE, Kingston DGl: Cytotoxic Triterpenoids from Acridocarpus vivy from the Madagascar Rain Forest. J Nat Prod 2004, 67:986-989.

37. Xie C, Kang J, Li Z, Schauss AG, Badger TM, Nagarajan S, Wu T, Wu X: The açaí flavonoid velutin is a potent anti-inflammatory agent; blockade of LPS-mediated TNF- $\alpha$ and IL-6 production through inhibiting NF-KB activation and MAPK pathway. J Nutr Biochem 2012, 23:1184-1191.

38. Saleh NAM, El-Negoumy SI, Aboud-Zaid MM: Flavonoids of Artemia judaica, A. Monosperma and A. herba-alba. Phytochemistry 1987, 26:3059-3064.
39. Carbonara T, Pascale R, Argentieri MP, Papadia P, Fanizzi P, Villanova L, Avato P: Phytochemical analysis of a herbal tea from Artemisia annua $\mathrm{L}$. J Pharm Biomed Anal 2012, 62:79-86.

40. Mahajan N, Rawal S, Verma M, Poddar M, Alok SA: Phytopharmacological overview on Ocimun species with special emphasis on Ocimun sanctum. Biomed Prev Nut 2013, 3:185-192.

41. Isobe T, Matsumi D, Morimoto Y, Nagata K, Ohsaki A: The Anti-Helicobacter pylori flavones in a Brazilian plant, Hyptis fasciculate, and the activity of methoxiflavones. Bio Pharm Bull 2006, 29:1039-1041.

42. Sheng $X$, Sun $Y$, Yin $Y$, Chen $T, X u$ Q: Cirsilineol inhibits proliferation of cancer cells by inducing apotosis via mitochondrial pathway. J Pharm Pharmacol 2008, 60:1523-1529.

43. Alvarez ME, Rotelli AE, Pelzer LE, Saad RJ, Giordano O: Phytochemical study and anti-inflammatory properties of Lampaya hieronymi Schum.ex Moldenke. /I Farmaco 2000, 55:502-505.

44. Yalçin FN, Ersöz T, Akbay P, Çaliş I, Dönmez AA, Sticher O: Phenolic, megastigmane, nucleotide, acetophenone and monoterpene glycosides from Phlomis samia and P. carica. Turk J Chem 2003, 27:703-711.

45. Abreu P, Bhraham H, Jannet HB, Mighri Z, Matthew S: Antioxidant compound from Ebenus pinnata. Fitoterapia 2007, 78:32-34.

46. Kwon HC, Lee KR: Phytochemical constituents of Artemisia japonica ssp. littoricola. Arch Pharm Res 2001, 24:194-197.

47. Kant K, Walia M, Agnihotri VK, Pathania V, Singh B: Evaluation of antioxidant activity of Picrorhiza kurroa (Leaves) extracts. Indian J Pharm Sci 2013, 75:324-329.

48. Jensen SR: Iridoids in Rothmannia globosa. Phytochemistry 1983, 22:1761-1765

49. Xu M, Sun Q, Su J, Wang J, Xu C, Zhang T, Sun Q: Microbial transformation of geniposide in Gardenia jasminnoides Ellis into genipin by Penicillium nigricans. Enzyme Microbiol Techno 2008, 42:440-444.

50. Koo H, Lim K, Jung H, Park E: Anti-inflammatory evaluation of gardenia extract, geniposide and genipin. J Ethnopharmacol 2006, 103:496-500.

51. Yang $Y$, Zhang T, Yu S, Ding Y, Zhang L, Qui C, Jin D: Transformation of geniposide into genipin by immobilized $\beta$-glucosidase in a two-phase aqueous-organic system. Molecules 2011, 16:4295-4303.

doi:10.1186/1472-6882-14-259

Cite this article as: Morales and Paredes: Antioxidant activities of Lampaya medicinalis extracts and their main chemical constituents. BMC Complementary and Alternative Medicine 2014 14:259.

\section{Submit your next manuscript to BioMed Central and take full advantage of:}

- Convenient online submission

- Thorough peer review

- No space constraints or color figure charges

- Immediate publication on acceptance

- Inclusion in PubMed, CAS, Scopus and Google Scholar

- Research which is freely available for redistribution 